\title{
Response to Andrews and Deen on Defining Activity Pacing
}

Citation for published version (APA):

Peters, M. L., Esteve, R., Ramírez-Maestre, C., \& López-Martínez, A. E. (2016). Response to Andrews and Deen on Defining Activity Pacing. The Journal of Pain, 17(12), 1363-1364.

https://doi.org/10.1016/j.jpain.2016.09.001

Document status and date:

Published: 01/12/2016

DOI:

10.1016/j.jpain.2016.09.001

Document Version:

Publisher's PDF, also known as Version of record

Document license:

Taverne

Please check the document version of this publication:

- A submitted manuscript is the version of the article upon submission and before peer-review. There can be important differences between the submitted version and the official published version of record.

People interested in the research are advised to contact the author for the final version of the publication, or visit the DOI to the publisher's website.

- The final author version and the galley proof are versions of the publication after peer review.

- The final published version features the final layout of the paper including the volume, issue and page numbers.

Link to publication

\footnotetext{
General rights rights.

- You may freely distribute the URL identifying the publication in the public portal. please follow below link for the End User Agreement:

www.umlib.nl/taverne-license

Take down policy

If you believe that this document breaches copyright please contact us at:

repository@maastrichtuniversity.nl

providing details and we will investigate your claim.
}

Copyright and moral rights for the publications made accessible in the public portal are retained by the authors and/or other copyright owners and it is a condition of accessing publications that users recognise and abide by the legal requirements associated with these

- Users may download and print one copy of any publication from the public portal for the purpose of private study or research.

- You may not further distribute the material or use it for any profit-making activity or commercial gain

If the publication is distributed under the terms of Article $25 \mathrm{fa}$ of the Dutch Copyright Act, indicated by the "Taverne" license above, 


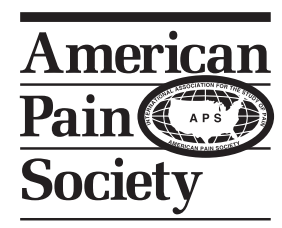

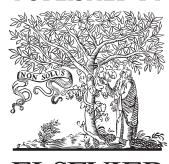

ELSEVIER
The Journal of Pain, Vol 17, No 12 (December), 2016: pp 1363-1364

Available online at www.jpain.org and www.sciencedirect.com

\section{Response to Andrews and Deen on Defining Activity Pacing}

To the Editor:

We thank Drs. Andrews and Deen for their letter ${ }^{1}$ and for once more bringing attention to the concept of activity pacing.

We agree that there is much confusion in the use of the term, "pacing." As Andrews and Deen discuss, ${ }^{1}$ recently several attempts toward clarification were made, $, 5,6,8$ but this has not led to a uniform conceptualization. One source of confusion relates to the use of the term pacing as being a set of behaviors taught during clinical intervention or as being a coping strategy used by patients with pain. ${ }^{10}$ This could for instance explain why "slowing down" is not considered by clinicians to be a pacing behavior ${ }^{4,6}$ whereas it might reflect spontaneous behavior that patients use to regulate their activity. ${ }^{10}$ This distinction may also be evident when defining the goal of activity pacing. Pain reduction is often not the main goal of activity pacing as taught in clinical practice, but it may be for patients when using pacing as a coping technique.

In the construction of the Activity Pattern Scale (APS) ${ }^{7}$ we aimed at assessing a variety of behaviors that patients use to cope with pain, including but not restricted to activity pacing. Following Nielson and colleagues ${ }^{9,10}$ we differentiated pacing behaviors not only according to the specific pacing technique (eg, taking breaks), but also according to the goals they serve. On the basis of the operant and energy conservation approach 3 main goals were identified: increasing activity level, conserving energy for valued activities, and pain reduction. We found preliminary evidence that differentiation of pacing according to the goal it serves is indeed important. Whereas pacing for the goal of increasing activity or conserving energy for valued activities was positively associated with daily functioning, pacing for pain reduction was not. ${ }^{7}$

As Andrews and Deen illustrate in their comprehensive framework, activity pacing can encompass a variety of behaviors and serve many different goals. The APS was designed as a concise instrument and included only strategies and goals most commonly considered. The framework might inform future attempts to construct a dedicated and comprehensive activity pacing instrument. Nevertheless, the main problem with any self-

Address reprint requests to Madelon L. Peters, PhD, Clinical Psychological Science, Maastricht University, PO Box 616, Maastricht 6200 MD, The Netherland. E-mail: madelon.peters@maastrichtuniversity.nl

$1526-5900 / \$ 36.00$

(C) 2016 by the American Pain Society

http://dx.doi.org/10.1016/j.jpain.2016.09.001 report measure is to know how patients understand and interpret the items. Validation should include qualitative analyses and assessment of actual behaviors by observation or ecological momentary assessment. Andrews and colleagues have already done important work in this area. ${ }^{2,3}$ We are currently validating the APS by comparing self-reported behavior with observed behavior in standardized situations.

The primary purpose of Andrews and Deen's letter was to generate discussion on future use of the term activity pacing. One option they suggest is to abandon the term altogether and replace it with a different label. However, we believe that this will not in itself resolve the issue, as any label might give rise to confusion when not properly defined. As an example, the label "activity modulation" that they introduce in the aforementioned framework as an alternative overarching concept could likewise encompass a variety of behaviors, including activity avoidance and overactivity. It is the accompanying definition and specification of sub (components) that clarifies the meaning of the label. We would argue that the label activity pacing can still be used, as long as one clearly defines what is meant by and subsumed under this label, just as this will be necessary for any other label. First and foremost it should be clear whether activity pacing is used to refer to a treatment strategy or to behaviors-taught or spontaneous-that patients actually use to cope with their pain.

Madelon L. Peters

Clinical Psychological Science, Maastricht University, Maastricht, The Netherlands

Rosa Esteve

Carmen Ramírez-Maestre Alicia E. López-Martínez Faculty of Psychology, University of Málaga, Málaga, Spain

\section{References}

1. Andrews NE, Deen M: Defining activity pacing: Is it time to jump off the merry-go-round? J Pain 17:1359-1362, 2016

2. Andrews NE, Strong J, Meredith PJ, Fleming JA: The relationship between overactivity and opioid use in chronic pain: A 5-day observational study. Pain 157: 466-474, 2016

3. Andrews NE, Strong J, Meredith PJ: Overactivity in chronic pain: Is it a valid construct? Pain 156:1991-2000, 2015 
4. Antcliff D, Campbell M, Woby S, Keeley P: Assessing the psychometric properties of an activity pacing questionnaire for chronic pain and fatigue. Phys Ther 95: 1274-1286, 2015

5. Antcliff D, Keeley P, Campbell M, Oldham J, Woby S: The development of an activity pacing questionnaire for chronic pain and/or fatigue: a Delphi technique. Physiother 99: 241-246, 2013

6. Cuperus N, Vliet Vlieland $\mathrm{T}$, Brodin $\mathrm{N}$, Hammond $\mathrm{A}$, Kjeken I, Lund $\mathrm{H}$, Murphy S, Neijland $\mathrm{Y}$, Opava $\mathrm{CH}$, Roskar S, Sargautyte R, Stamm T, Mata XT, Uhlig T, Zangi $\mathrm{H}$, van den Ende $\mathrm{CH}$ : Characterizing the concept of activity pacing as a non-pharmacological intervention in rheumatology care: Results of an international Delphi survey. Scand J Rheumatol 4:1-9, 2015
7. Esteve R, Ramirez-Maestre C, Peters ML, SerranoIbanez ER, Ruiz-Parraga GT, Lopez-Martinez AE: Development and initial validation of the activity patterns scale in patients with chronic pain. J Pain 17:451-461, 2016

8. Jamieson-Lega K, Berry R, Brown CA: Pacing: A concept analysis of the chronic pain intervention. Pain Res Manag $18: 207-213,2013$

9. Nielson WR, Jensen MP, Karsdorp PA, Vlaeyen JW: A content analysis of activity pacing in chronic pain: What are we measuring and why? Clin J Pain 30:639-645, 2014

10. Nielson WR, Jensen MP, Karsdorp PA, Vlaeyen JW: Activity pacing in chronic pain: Concepts, evidence, and future directions. Clin J Pain 29:461-468, 2013 